\title{
PERBEDAAN KEMAMPUAN BERPIKIR KRITIS LAKI-LAKI DAN PEREMPUAN PADA MATERI SISTEM PEREDARAN DARAH MATA PELAJARAN BIOLOGI KELAS XI MIPA MAN I BANYUASIN III
}

\author{
Erna Dwi Yanti ${ }^{1)}$ a), Indah Wigati $^{2)}$, Ummi Hiras Habisukan ${ }^{3)}$ \\ 1) 2) 3) Pendidikan Biologi Fakultas Tarbiyah dan Keguruan Uin Raden Fatah Palembang \\ Jl. Prof. K.H. Zainal Abidin Fikri No.1 A KM 3,5 Palembang 30126, Indonesia \\ ${ }^{a)}$ Ernadwiyanti4@gmail.com \\ Telp: +62-822-8039-7383
}

\begin{abstract}
The ability of critical thinking is very important to have. If the students have an ability of critical thinking, they students can solve the problems that facing them on the lesson study especially biology. Based on that problem, the writer was conducted a research which have the aim to know the difference between the ability of male students' and female students' critical thinking on blood circulation system material in biology lesson of XI MIPA MAN 1 Banyuasin. This research was conducted on july 17, 2018 At XI MIPA class of MAN 1 Banyuasin. This research was descriptive analysis research. The subject of this research was the students of XI MIPA 1, XI MIPA 2, XI MIPA 3 XI MIPA 4 of MAN 1 Banyuasin with the total of the students are 157 students. Data analyzing technique used probability sampling technique that is proportionate stratified random sampling with descriptive analysis method, the result of this research showed that the ability of male students' critical thinking are low with the average 13.15. The ability of female students' critical thinking are high with the average 14.05 . There is the difference between the ability of male studets' and female students' critical thinking. In conclusion, the ability of female students' critical thinking is higher than male student's in MAN 1 Banyuasin.
\end{abstract}

Key words : Critical thinking, gender, circulatory system

\begin{abstract}
ABSTRAK
Kemampuan berpikir kritis sangat penting dimiliki. Jika siswa memiliki kemampuan berpikir kritis, siswa dapat memecahkan persoalan-persoalan yang dihadapi dalam pelajaran terutama dalam pelajran Biologi. Berdasarkan hal tersebut dilakukan penelitian yang bertujuan untuk mengetahui perbedaan kemampuan berpikir kritis pada siswa laki-laki dan perempuan pada materi sistem peredaran darah mata pelajaran Biologi Kelas XI MIPA MAN 1 Banyuasin III. Penelitian ini dilaksanakan pada 17 Juli 2018 dikelas X1 MIPA MAN Banyuasi III. Penelitian ini merupakan penelitian deskrtif analisis. Subjek penelitian adalah siswa kelas XI MIPA 1, XI MIPA 2, XI MIPA 3 dan XI MIPA 4 MAN 1 Banyuasin III dengan jumlah siswa 157. Teknik pengumpulan data berupa tes. Teknik analisis data menggunakan teknik Probality sampling yaitu Proportionate stratified random sampling dengan metode deskritif analisis. Hasil penelitian penelitian menunjukan bahwa kemampuan berpikir kritis laki-laki yang dicapai rendah dengan rata-rata 13.15 . Kemampuan berpikir kritis perempuan yang dicapai tinggi dengan rata-rata 14.05. Adanya perbedaan kemapuan berpikir kritis siswa laki-laki dan perempuan. Berdasarkan Hal tersebut kemampuan berpikir kritis siswa perempuan lebih tinggi dibandingkan siswa laki-laki di MAN 1 Banyuasin III.
\end{abstract}

Kata kunci : Berpikir Kritis, Gender, Sistem peredaran darah 


\section{PENDAHULUAN}

Berpikir merupakan hubungan antara bagian-bagian pengetahuan kita dan proses dialektik. Untuk dapat meletakkan hubungan-hubungan antara pengetahuan dengan tepat selama berpikir, pikiran mengadakan tanya jawab dengan pikiran itu sendiri. Berbagai proses mental seperti imajinasi, penalaran, abstrak, penilaian dan pemecahan masalah merupakan proses yang menghasilkan representasi mental yang baru melalui transformasi, informasi yang melibatkan interaksi yang komplek dalam berpikir artinya menggunakan akal budi untuk mempertimbangkan dan memutuskan sesuatu (Jensen, 2015).

Masalah kemajemukan siswa di sekolah adalah salah satu topik yang menjadi pokok bahasan dan penelitian dunia pendidikan.Pada proses pembelajaran yang utama adalah perbedaan-perbedaan pada diri siswa harus diakui dalam dunia pendidikan, perbedaan gender cukup mucul terutama di sekolah umum, perbedaan yang tampak jelas adalah perbedaan secara fisik. Postur tubuh anak laki-laki lebih besar dan kuat meskipun anak perempuan lebih cepat pertumbuhannya dari pada anak laki-laki. Anak laki-laki biasanya lebih unggul dalam bidang keterampilan dibandingkan anak perempuan (Soemardjo, 2013). Namun demikian, anak perempuan dinyatakan lebih unggul dalam hal kemampuan lisan, karena anak laki-laki sering mengalami masalah dalam hal berbahasa. Secara biologis, perbedaan kemampuan yang terlibat dalam pemerosesan bahasa tersebut dapat dikaitkan dengan perbedaan otak perempuan dan laki-laki. Aspek psikososial dari perempuan dan laki-laki merupakan gender. Di dunia pendidikan di sekolah adanya hubungan antara gender dengan kemampuan berpikir kritis. Bahwa anak laki-laki menunjukkan masalah-masalah yang banyak di bandingkan perempuan sedangkan perempuan lebih bagus dalam mengerjakan tugas-tugas lisan di tahuntahun awal dan dapat dipertahankan.

Menurut Muhlisin (2016), Pemikiran siswa belum kritis karena dapat pada argument siswa masi terdapat yang tidak sesuai, memberikan lebih sedikit asumsi logis, dan evaluasi tanpa syarat berdasarkan fakta. Pada kenyataannya di sekolah, pembelajaran biologi belum banyak meningkan kecakapan dan kemampuan berpikir kritis. Sehingga hasil belajar kognitif masih pada tingkat rendah. Siswa diharapkan menyerap informasi secara pasif dan kemudian mengingatnya pada saat mengikuti tes. Pembelajaran yang seperti ini, mengakibatkan siswa tidak memperoleh pengalaman untuk mengembangan kemampuan berpikir kritis. Kondisi inilah yang menyebabkan rendahnya kemampuan berpikir kritis.

Rendahnya kemampuan berpikir kritis juga terjadi pada siswa di MAN 1 Pangkalan Balai. Berdasarkan observasi yang dilakukan pada hari Senin, 20 November 2017. Berdasarkan pengamatan secara langsung pada siswa pada saat proses pembelajaran di kelas XI MIPA di Madrasah Aliyah Negeri 1 Banyuasin III dapat diketahui bahwa ada beberapa masalah terkait dengan kemampuan berpikir kritis, bahwa sebagian siswa mengalami kesulitan dalam memahami konsep Biologi dan sebagian siswa dalam kemampuan berpikir kritis masi rendah ketika guru memberikan pertanyaan yang akan dijawab. Berdasarkan hasil wawancara guru mata pelajaran Biologi dapat disimpulkan bahwa sebagian kemampuan siswa untuk berpikir kritis masih rendah pada mata pelajaran biologi.

Selain itu juga observasi dengan menggunakan 16 butir soal essay yang berbasis indikator berpikir kritis menurut Fascione berbasis indikator kemampuan berpikir kritis, dimana dari hasil nilai ratarata yang didapatkan dari kelas (XI MIPA) bahwa kelompok siswa laki-laki memiliki hasil nilai 46,54\% lebih tinggi dari pada siswa perempuan yaitu hasil nilai $57,69 \%$. Dari hasil nilai yang diperoleh tersebut dapat dilihat bahwa semua indikator berpikir kritis belum tercapai secara maksimal. Hasil tersebut menunjukan bahwa ada kemampuan yang berbeda antara siswa laki-laki dan perempuan dari aspek berpikir kritis. Perbedaan hasil yang ditunjukan pada hakikatnya aktivitas otak laki-laki terfokus pada otak kiri sedangkan 
perempuan lebih terfokus pada otak kiri dan kanan.

Berdasarkan latar belakang dan permasalahan di atas, maka peneliti tetarik untuk melakukan penelitian tentang Perbedaan Kemampuan Berpikir Kritis Laki-Laki dan Perempuan Pada Materi Sistem Peredaran Darah Mata Pelajaran Biologi Kelas XI MIPA MAN I Banyuasin III.

\section{METODOLOGI PENELITIAN}

Penelitian ini dilaksanakan pada tanggal 16 Juli 2018 di Madrasah Aliyah Negeri 1 Banyuasin III. Penelitian ini menggunakan metode deskriptif analisis dengan pendekatan kualitatif. Adapun yang menjadi sampel dalam penelitian ini adalah siswa atau siswi kelas XI MIPA. Subyek yang saya ambil sembanyak 157 siswa dan presisi yang ditetapkan atau tingkat signifikansi 0,05, maka diperoleh besarnya obyek pada penelitian ini adalah 20 siswa yaitu 10 siswa laki-laki dan 10 siswa perempuan. Obyek yang digunakan yaitu probalitity sampling yaitu Proportionate stratified random sampling. Teknik pengumpulan data diambil melalui tes soal berupa essay, observasi dan dokumentasi. Teknik analisis data yang digunakan metode triangulasi dengan Reduksi data, Penyajian data dan Penarikan simpulan

\section{HASIL DAN PEMBAHASAN}

Kemampuan berpikir kritis siswa Laki-laki dapat dihitung berdasarkan indikator kemampuan berpikir kritis menurut Fasceone. Hasil tersebut disajikan pada gambar 1.

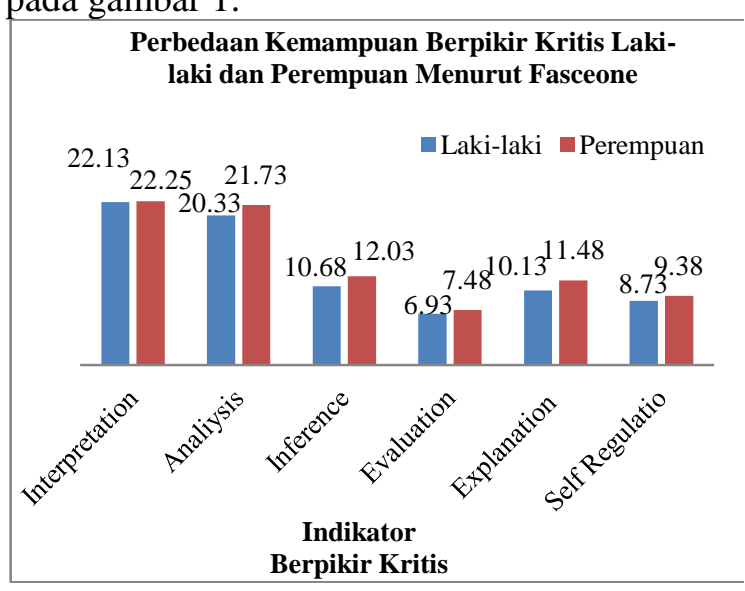

\section{Gambar 1 Perbedaan Kemanpuan Berpikir Kritis Laki-laki Dan Perempuan}

Hasil nilai rata-rata tersebut memberikan maknan bahwa ada perbedaan tetapi tidak signifikan dalam kemampuan berpikir pada siswa laki-laki dan siswa perempuan. Karena dalam menentukan siswa laki-laki dan perempuan ini, berdasarkan yang dipilih oleh guru mata pelajaran sehingga hasil yang diperoleh tidak signifikan. Hasil temuan ini sesuai yang diungkapkan oleh Heong (di dalam Cahyono, 2017), bahwa gender prestasi akademik, dan status sosial ekonomi tidak mempengaruhi kemampuan berpikir siswa. Sejalan hasil tersebut, Sasser (2010) juga melaporkan bahwa perbedaan jenis kelamin tidak menunjukkan perbedaan yang signifikan dalam hal kemampuan berpikir divergen.

\section{Kemampuan Berpikir Kritis Siswa Laki- Laki}

Berdasarkan data hasil yang diperoleh, dilihat dari gambar 1 perbedaan kemampuan berpikir kritis laki-laki pada tahapan indikator interpretation, siswa lakilaki menuliskan yang diketahui dari soal secara lengkap dan jelas namun belum tepat, karena hanya mengekspresikan makna berdasarkan yang terkait dalam pengalaman dan situasi. Siswa laki-laki dapat menuliskan secara efektif dan efisien. Sehingga waktu yang dibutuhkan siswa laki-laki untuk mengekspresikan makna dan memahami stuasi, lebih singkat di bandingkan perempuan.

Pada tahapan analysis, siswa laki-laki dalam mengidentifikasi hubungan inferensial yang diinginkan dan aktual diantara pertanyaan, konsep, deskripsi, ataupun opini sudah tepat tetapi kurang jelas dalam menganalisis agumen dalam mengevaluasi ide. Inference, siswa laki-laki mampu menarik kesimpulan yang sesuai apa yang diminta soal dan alasan yang digunakan untuk membuat kesimpualan sudah sudah tepat untuk mendukung kesimpulan yang dibuat. 
Pada tahapan evaluation, siswa lakilaki dalam kredibilitas pernyataan yang digunakan dalam soal untuk menyampaikan pemikiran, keputusa dan alasan sudah jelas tetapi kurang tepat dalam persepsinya. Pada indikator explanation dalam setiap langkah pengambilan keputusan maupun kesimpulan didasari dengan alasan yang cenderung singkat, jelas, relevan dan sering menggunakan sketsa gambar untuk memjelaskan alasan tersebut tidak langsung menjawab dengan cepat namun selalu berhati-hati sehingga waktu yang diperlukan cenderung lama. Self regulation Siswa mampu mampu memberikan penalaran lebih lanjut tentang evaluasi untuk penilaian yang disimpulan oleh diri sendiri, mampu memvalidasi yang terdapat pada soal serta dapat membuat contoh kasus seperti masalah soal yang diberikan dengan baik tetapi kurang tepat.

Berdasarkan pengamatan pada keenam indikator kemampuan berpikir kritis tersebut, laki-laki tidak terlalu menyukai menulis, sehingga laki-laki hanya menuliskan apa yang dianggap penting saja. Ketika melakukan perhitungan juga sebagian perhitungan dilakukan hanya dalam ingatan (tidak tertulis), hanya perhitungan yang dianggap penting yang ditulis. Hal ini sejalan dengan NAPLAN (National Assessment Program-Literacy and Numeracy) mengatakan bahwa anak laki-laki secara teratur mengalahkan anak perempuan di berhitung, dan anak perempuan secara konsisten mengalahkan anak laki-laki dalam membaca, menulis, mengeja, dan tata bahasa.

\section{Kemampuan Berpikir Kritis Siswa Perempuan}

Berdasarkan data hasil yang diperoleh, dilihat dari gambar 1 perbedaan kemampuan berpikir kritis laki-laki dan perempuan bahwa nilai perempuan lebih tinggi karena pada tahapan indikator interpretasi, siswa perempuan mampu memahami dan mengekspresikan makna yang di berikan dalam soal sehingga mampu memahami situasi, data, kejadian, penilaian, konvensi, keyakinan, peraturan, prosedur, atau kriteria.
Hal tersebut dapat dilihat dari kemampuan menuliskan jawaban yang ditanyakan dengan tepat dan jelas. Pada tahapan analysis, siswa dapat mengidentifikasi hubungan inferensial yang diinginkan dan aktual dalam soal yang ditanyakan dengan jelas dan tepat. Siswa dalam penarikan kesimpulan Inference, sudah sesuai dengan apa yang diminta soal dan alasan yang digunakan untuk membuat kesimpulan juga sudah tepat untuk mendukung kesimpulan yang dibuat dan relevan namun cenderung terperinci, lengkap dan jelas. Pada indikator evaluation siswa mampu memberikan pedapat (membenarkan atau mengklarifikasi) lebih lanjut tentang kesimpulan akhir, mampu menjelaskan istilah yang terdapat pada soal serta dapat membuat contoh kasus seperti masalah soal yang diberikan dengan baik.

Pada tahapan explanation dalam setiap langkah pengambilan keputusan, maupun menyimpulkan didasari dengan alasan yang cenderung terperinci, lengkap, jelas dan relevan, untuk memberikan alasan tersebut tidak langsung menjawab dengan cepat namun selalu berhati-hati sehingga waktu yang diperlukan cenderung lama. Dan self regulation siswa mampu memberikan penalaran lebih lanjut tentang tentang evaluasi untuk penilaian yang disimpulan oleh diri sendiri, mampu memvalidasi yang terdapat pada soal serta dapat membuat contoh kasus seperti masalah soal yang diberikan dengan baik dan tepat.

Temuan penelitian ini sesuai dengan temuan dari Ricketts (2004), yaitu nilai perempuan lebih tinggi dari nilai laki-laki dalam hal kemampuan berpikir kritis analisis. Temuan penelitian ini dapat dijelaskan sebagai berikut. Pada perempuan daerah otak yang berhubungan dengan fungsi bahasa bekerja lebih keras yang mengakibatkan kemampuan bahasa perempuan lebih tinggi dibanding laki-laki. Bahasa merupakan alat yang digunakan untuk menyampaikan pikiran. Kemampuan penggunakaan bahasa dengan gramatika yang bagus merupakan indikator kemampuan berpikir tinggi. Menurut Guiller (dalam Cahyono, 2017) bahwa 
perempuan mempunyai kemampuan lebih dalam menyampaikan pendapatnya ke orang lain.

\section{Perbedaan Kemampuan Berpikir Kritis Siswa Laki-Laki Dan Perempuan}

Maka dari kedua penjelas tersebut bahwa adanya perbedaan gender dilihat bahwa siswa perempuan lebih tinggi berpikir kritisnya dibandingkan siswa lakilaki. Hal tersebut dilihat dari pencapaian nilai rata-rata per-indikator yang dicapai dalam menjawab soal. Hal tersebut dikarenakan siswa perempuan lebih teperinci dan teliti dalam menjawab soal, karena pola berpikir perempuan berbeda dengan laki-laki. Pada otak daerah otak yang berhubungan dengan fungsi bahasa bekerja lebih keras yang mengakibatkan kemampuan bahasa perempuan lebih tinggi dibandingkan laki-laki. Bahasa merupakan alat yang digunakan untuk menyampaikan pikiran. Kemampuan penggunakaan bahasa dengan gramatika yang bagus merupakan indikator kemampuan berpikir tinggi. Oleh karena itu bahasa perempuan lebih terperinci dalam menjawab setiap soal, sehingga nilai yang didapat setiap soal bernilai lebih tinggi dibandingkan laki-laki.

Hasil temuan ini sesuai yang di ungkapkan Mahanal (2011) bahwa gender terhadap perbedaan kemampuan berpikir kritis siswa SMA di Kota Malang, dijelaskan kelompok siswa perempuan menunjukkan kemampuan berpikir kritis lebih tinggi di bandingkan kelompok siswa laki-laki. Beberapa hasil penelitian tersebut dapat dijelaskan karena perempuan lebih unggul dalam hal berbahasa. Bahasa dapat dipandang sebagai alat untuk menyampaikan pikiran seseorang. Hal ini sesuai dengan penjelasan De Bono (dalam Mahanal, 2011) juga mengungkapkan bahwa bahasa atau sistematika perlambangan verbal adalah alat penting dalam berpikir, bahkan mungkin yang terpenting, sehingga berpikir kerap juga dipandang sebagai percakapan batin. Kemampuan berpikir kritis berbeda antara siswa laki-laki dan perempuan. Perbedaan perhitungan yang ditunjukkan tersebut dapat disebabkan oleh kemampuan siswa dalam hal berbahasa. Perbedaan kemampuan tersebut terkait dengan perbedaan struktur bagian otak laki-laki dan perempuan yang terlibat dalam pemrosesan bahasa. Menurut Zaidi (2010) laki-laki dan perempuan berbeda dalam hal proses belajar dan perkembangan berbahasa. Beberapa penelitian telah melaporkan bahwa siswa perempuan lebih unggul dalam kemampuan verbal. Hal yang sama dijelaskan oleh Shaywitz dalam Cahyono, (2017) selama tugas fonologi, aktivasi otak pada laki-laki terfokus pada daerah bagian kiri frontal gyrus, sedangkan pada wanita menunjukkan pola aktivasi yang melibatkan saraf lebih menyebar di kedua inferior frontal gyrus kiri dan kanan. Informasi tersebut memberikan bukti adanya variasi pada tingkat pengolahan bahasa pada lakilaki dan perempuan.

Secara biologis, perbedaan beberapa struktur otak memungkinkan siswa laki-laki dan siswa perempuan berbeda dalam beberapa hal seperti kemampuan memproses, menanggapi informasi, emosi, motivasi, prilaku dan menyimpan informasi jangka panjang. Pada daerah sistem limbik pada laki-laki dan perempuan memiliki struktur yang berbeda. Lebih lanjut dijelaskan bahwa perempuan umumnya memiliki hippocampus lebih besar daripada laki-laki, sehingga berpotensi meningkatkan memori penyimpanan jangka panjang yang lebih baik. Selain itu, bagian otak lain yang memiliki struktur berbeda antara laki-laki dan perempuan adalah bagian cerebral cortex yang mengontrol berpikir, pengambilan keputusan, dan fungsi intelektual. Lebih lanjut Sasser (2010) mengungkapkan bahwa otak perempuan menerima sekitar $20 \%$ lebih banyak aliran darah dan memiliki koneksi saraf yang lebih banyak. Menurut Witelson dkk (dalam Cahyono, 2017) hal tersebut memungkinkan perempuan dapat memproses dan menanggapi informasi yang lebih cepat

\section{KESIMPULAN}

Berdasarkan hasil penelitian yang telah dilaksanakan dan pembahasan yang telah dipaparkan, maka dapat disimpulakan bahwa terdapat perbedaan gender, pada 
siswa perempuan memperoleh rata-rata 14.05 sedangkan pada siswa laki-laki memperoleh rata-rata 13.15 . Jadi rata-rata siswa perempuan lebih tinggi kemampuan berpikir kritisnya dibandingkan siswa lakilaki di MAN 1 Banyuasin III.

\section{UCAPAN TERIMA KASIH}

Penulis mengucapkan terima kasih kepada pihak-pihak yang telah membantu dalam penelitian ini terutama kepada pihak sekolah MAN 1 Banyuasin III dan dosendosen yang telah membimbing saya.

\section{DAFTAR PUSTAKA}

Cahyono, B. 2017. Analisis Keterampilan Berpikir Kritis dalam Memecahkan Masalah Ditinjau Perbedaan Gender. E-Jurnal. ISSN. 2579-7646. 8 (1). 50-64.

Jensen, C. 2015. Keterampilan Berpikir Kritis Dan Kreatif. Raja Grafindo Persada: Jakarta.

Mahanal, S. 2011. Pengaruh Pembelajaran Berbasis Proyek pada Mata pelajaran Biologi dan Gender terhadap Keterampilan Metakognisi dan Kemampuan Berpikir Kritis Siswa SMA di Malang. Laporan Penelitian. Lemlit UM :Malang.

Muhlisin, A. 2016. Improving critical thinking skills of college students through RMS model for learning basic concepts in science. AsiaPacific Forum on Science Learning and Teaching. EdUHK APFSLT. 17. 1. Article 12.

Ricketts, J.C., Rudd. R. 2004.Critical Thinking Skills of FFA Leaders.Journal of Southern Agricultural education Research 7.54, (1), 2004.(Online). http:// www. jsaer. org/pdf/Vol54/54-01007.pdf. diakses pada Rabu,
Tanggal 01 Agustus 2018. Pukul 20:10 WIB.

Riyanto. 2013. Statistic Deskritif. Nuha Medika: Yogyakarta.

Sasser, L. 2010. Brain Differences between Genders. (http://www.faccs. org/ assets/ Conventions/ Convention10/ Workshops/ Sasser GenderDifferences- in- Learning. pdf). Diakses pada hari Kamis tanggal 02 Agustus 2018. Pukul 09:26 WIB.

Soemardjo. 2013. Mengajar Berpikir. Erlangga: Jakarta.

Sugiyono. 2011. Metode Penelitian Kuantitatif, Kualitatif dan $R \& D$. Alfabeta: Bandung.

Zaidi, Z. F. 2010. Gender Differences in Human Brain. (http:// www.benthamscience.com/open/t oanatj/articles/V002/37TOANAT J.AReview. The Open Anatomy Journal, 2010, 2, 37-55, (Online), pdf), Diakses pada hari Kamis tanggal 02 Agustus 2018. Pukul 09:19 WIB. 